TITLE:

\title{
ANOTHER NEW CHAETOGNATH FROM MALAY WATERS, WITH A PROPOSAL OF GROUPING SOME SPECIES OF SAGITTA INTO SUBGENERA
}

\section{$\operatorname{AUTHOR}(S)$ :}

Tokioka, Takasi; Pathansali, D.

\section{CITATION:}

Tokioka, Takasi ...[et al]. ANOTHER NEW CHAETOGNATH FROM MALAY WATERS, WITH A PROPOSAL OF GROUPING SOME SPECIES OF SAGITTA INTO SUBGENERA. PUBLICATIONS OF THE SETO MARINE BIOLOGICAL LABORATORY 1963, 11(1): 119-123

\section{ISSUE DATE:}

1963-07-20

URL:

http://hdl.handle.net/2433/175321

RIGHT: 


\title{
ANOTHER NEW CHAETOGNATH FROM MALAY WATERS, WITH A PROPOSAL OF GROUPING SOME SPECIES OF SAGITTA INTO SUBGENERA
}

\author{
TAKASI TOKIOKA \\ Seto Marine Biological Laboratory, Sirahama, Japan \\ and \\ D. PATHANSALI \\ Fisheries Laboratory, Glugor, Penang
}

With Plate VII and 1 Text-figure

\begin{abstract}
After we had submitted our manuscript on a new chaetognath, Sagitta johorensis, from Malay waters to the editorial board of the Publ. Seto Mar. Biol. Lab., another new form was discovered in the material from Penang waters. This belongs to the neglecta-group, too, but it is very distinctive in having the posterior fin beginning at the trunk-tail septum. As so many species are now included in the neglecta-group, we have become aware of the necessity of subdividing the genus Sagitta or grouping some species of Sagitta into subgenera as mentioned in the paragraph of remarks.

Before closing the introductory note, we want to express here our hearty thanks to the Director of Fisheries, Federation of Malaya, for his kindness in giving us the chance to study the material and to publish the results obtained.
\end{abstract}

\section{Sagitta demipenna n. sp.}

A small rigid species resembling superficially Sagitta bedfordii DoNCASTER commonly found in Penang waters, up to $4.3 \mathrm{~mm}$ in body length (including tail fin), and with the tail segment (including tail fin) occupying 36-41\% of the total length. Head rather slender and bluntly pointed at the tip in ones with hooks closed as in Sagitta regularis AIDA. Neck inconspicuous, collarette is distinctive in the range from the neck to the frontal end of the anterior fin, but diminishes in thickness posteriorly; it may continue further posteriorly to the seminal vesicle as a very faint thickening. Constriction at the

Publ. Seto Mar. Biol. Lab., XI (1), 1963. (Article 8) 
trunk-tail septum is indiscernible. The body is nearly of the same width throughout the length. Lateral field is narrow, muscles fairly developed and resultantly the body looks opaque.

Anterior fin begins behind the ventral ganglion, though the distance to the posterior end of the ganglion is very small, usually less than one fourth of the ganglion length, or $0.5-1.1 \%$ of the total body length. It is narrow, (15 to $19 \%$ of the body length) and wholly rayed, rays near the anterior end are set perpendicularly to the fin base. Posterior fin begins at the trunk-tail septum, nearly as long as or very slightly longer than the anterior fin (19 to $21 \%$ of the body length) and is smoothly rounded in outline; rayless-zone is absent and a few rays near the frontal end are set vertically to the base. Tail fin is somewhat tall. The pigmented area of eye is relatively large and roughly roundish in outline (Figure D). Corona ciliata (Figs. B and C) begins on the neck, as long as the head, and with two sinuses along the lateral side, each marked with a large sensory spot on the outerside; anterior sinus is very distinct, but the posterior one is somewhat inconspicuous. Intestinal diverticula very distinct.

Formulae of sixteen examined specimens are :

\begin{tabular}{|c|c|c|c|c|c|c|}
\hline $\begin{array}{l}\text { Sp. } \\
\text { No. }\end{array}$ & $\begin{array}{l}\text { Total length } \\
\text { in } \mathrm{mm}\end{array}$ & $\begin{array}{l}\text { Length of } \\
\text { tail segment } \\
\text { as \% }\end{array}$ & Hooks & $\begin{array}{c}\text { Anterior } \\
\text { teeth }\end{array}$ & $\begin{array}{l}\text { Posterior } \\
\text { teeth }\end{array}$ & $\begin{array}{l}\text { Number of } \\
\text { mature eggs }\end{array}$ \\
\hline 1 & 3.1 & 36 & $10-10$ & $3-3$ & $4-4$ & - \\
\hline 2 & $\begin{array}{c}3.4 \\
\text { (2 specimens) }\end{array}$ & $36-39$ & $9-10$ & $2-3$ & $4-5$ & - \\
\hline 3 & 3.5 & 39 & $10-10$ & $3-3$ & $5-5$ & - \\
\hline 4 & 3.6 & 37 & $10-10$ & $3-3$ & $4-4$ & - \\
\hline 5 & $\begin{array}{c}3.7 \\
(2 \text { specimens })\end{array}$ & $37-38$ & $10-10$ & $2-3$ & $4-5$ & - \\
\hline 6 & $\begin{array}{c}3.8 \\
\text { (2 specimens) }\end{array}$ & 38 & $9-10$ & $3-4$ & $4-6$ & - \\
\hline 7 & 3.8 & 36.4 & $9-9$ & $2-3$ & $5-5$ & 4 \\
\hline 8 & 3.8 & 36.8 & $9-9$ & $3-3$ & $5-6$ & 6 \\
\hline 9 & 3.8 & 38.6 & $9-9$ & $3-4$ & $5-5$ & 0 \\
\hline 10 & 3.9 & 38.9 & $8-9$ & $3-3$ & $4-5$ & 3 \\
\hline 11 & 4.0 & 39 & $10-10$ & $3-3$ & $5-6$ & - \\
\hline 12 & 4.0 & 39.1 & $9-10$ & $3-3$ & $6-6$ & 2 \\
\hline 13 & 4.3 & 41.0 & $8-9$ & $4-4$ & $5-5$ & 4 \\
\hline
\end{tabular}

Hooks slender. Teeth are comparatively numerous for such small body sizes. The anterior teeth are very slender and as long as posterior ones, the rows meet each other at an acute angle. There is none or only a single tooth out of the wing of the vestibular ridge.

The ovary reaches anteriorly the frontal end of the anterior fin at the maximum. Fully matured eggs are less than six in examined specimens. As 
they are so large for such small body sizes, they are always arranged in a single series, but never form two, right and left, rows. Seminal vesicle (Textfig. 1 and Fig. G in Plate) is elongate, with a small glandular area at the anterior end. It is situated just behind the posterior fin, but fairly apart from the base of the tail fin. The prominence at the opening of seminal receptacle is rather low.

Remarks: This species is quite unique in having the posterior fin beginning at the trunk-tail septum. Other characters conform well to those of the neglecta-group. The present species may safely be accepted as a new species and constitutes the twelfth member of the neglecta-group. Six specimens,

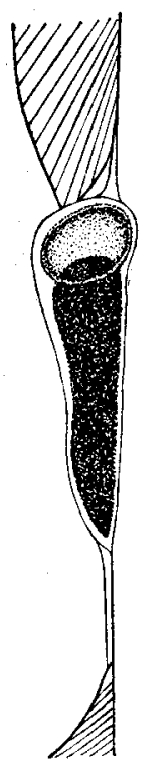

Text-fig. 1. Segitta demipenna n. sp. Matured seminal vesicle, enlarged.

Nos. $7-10,12$ and 13 in the formula table, are deposited at the Seto Marine Biological Laboratory as syntypes; their heads are all dissected. Other specimens are kept at the Fisheries Laboratory, Penang as paratypes.

Now reviewing the Indo-Pacific chaetognath fauna, we are impressed much by the abundance of species belonging to the neglecta-group. This group has a dozen species today and is well defined by the following features:

1) Rather rigid body, with relatively long tail segment, 2) existence of intestinal diverticula, 3) corona ciliata beginning below the level of eyes, 4) both anterior and posterior fins wholly rayed and, at least, near the anterior end rays are set perpendicularly to the base; tail fin is rather tall; 5) seminal 
vesicle is situated usually just behind the posterior fin and apart for a considerable distance from the base of the tail fin; in no species is the anterior glandular portion differentiated in external appearance; 6 ) the pigmented area of eye is rather large and roundish in outline, except for S. regularis, and 7). most species, excepting $S$. neglecta and S. regularis, are of the inlet- or the neritic waters.

We suppose it may be rather convenient to treat all the species of the neglecta-group under a common subgeneric name and propose here the subgenus Aidanosagitta for this purpose. This is to record the works of the late Dr. T. AIDA who examined the chaetognath fauna of the western North Pacific for the first time in 1897 and described the first two species of this subgenus. This subgenus includes the following twelve species:

1. Sagitta bedfordii Doncaster, 1902

2. Sagitta crassa ToKIoKA, 1938

3. Sagitta crassa f. naikaiensis Tок IокA, 1939

4. Sagitta crassa f. tumida (TokioKA), 1939

5. Sagitta delicata TокіокA, 1939

6. Sagitta demipenna ToKioka and Pathansali, 1963

7. Sagitta johorensis PATHANSAII and ToKIOKA, 1963

8. Sagitta neglecta AIDA, 1897

9. Sagitta oceanica GREY, 1930

10. Sagitta parva OYE, 1918

11. Sagitta regularis AIDA, 1897

12. Sagitta tropica ToKIoKA, 1942

For the same reason, we wish to propose another subgenus Serratosagitta to cover the following six species, of which the validity of the last two species is somewhat doubtful, that is characterized by 1) serrated hooks, 2) very small and elongate pigmented area of eye, 3 ) corona ciliata generally beginning in front of the level of the eyes and very elongate, 4) absence of intestinal diverticula, 5) anterior fin wholly rayed and posterior fin with a narrow inconspicuous rayless zone along the base of the anterior half, 6) seminal vesicle situated just behind the posterior fin and apart widely from the tail fin, and 7 ) the existence of a remarkable swelling near the middle of vas deferens.

1. Sagitta pacifica TокіокA, 1940

2. Sagitta pseudoserratodentata Tокіока, 1939

3. Sagitta serratodentata KROHN, 1853

4. Sagitta tasmanica Tномson, 1947

(5) Sagitta bierii Alvariño, 1961

(6) Sagitta selkirki FAGETTI, 1958 ? ? Sagitta tasmanica 


\section{EXPLANATION OF PLATE VII}

\section{Sagitta demipenna n. sp.}
A. Entire animal, dorsal side. $\times 47$
B. Anterior part of body, dorsal side. $\times 73$
C. A shorter corona ciliata. $\times 73$
D. Eyes. $\times 200$
E. Anterior and posterior teeth. $\times 440$
F. Posterior half of the trunk containing six mature eggs. $\times 47$
G. Seminal vesicle, not yet fully matured. $\times 73$ 
Publ. Seto Mar. Biol. Lab., XI, 1 (1963) PLATE VII

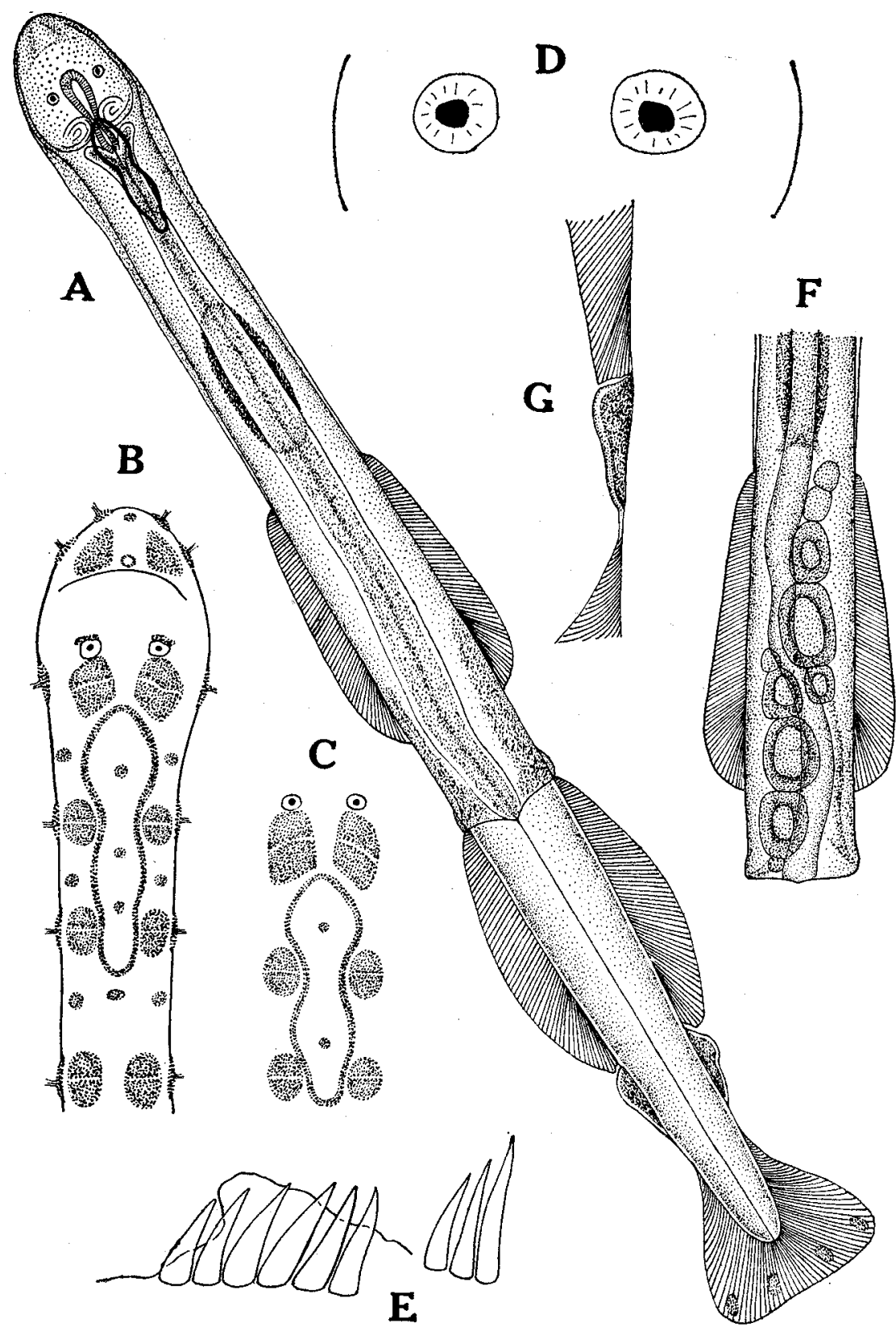

T. Tokioka and D. Pathansali: Another New Chaetognath from Malay Waters, 